ISSN 1989 - 9572

DOI: 10.47750/jett.2020.11.01.003

\title{
Increasing Motivation of Primary School Pupils' Studying
}

Viktoriia I. Prokopchuk ${ }^{1}$ Iryna Revenko ${ }^{2}$

Yuliya M. Demchenko ${ }^{3}$

Olga B. Blaga ${ }^{4}$

Vitaliia V. Tarasova ${ }^{5}$

\section{Journal for Educators, Teachers and Trainers, Vol. 11 (1)}

\section{https://jett.labosfor.com/}

Date of reception: 03 March 2020

Date of revision: 02 June 2020

Date of acceptance: 01 August 2020

Viktoriia I. Prokopchuk, Iryna Revenko, Yuliya M. Demchenko, Olga B. Blaga, Vitaliia V. Tarasova (2020). Increasing Motivation of Primary School Pupils' Studying. Journal for Educators, Teachers and Trainers, Vol. 11(1). 19 - 29.

${ }^{1}$ Department of Playing Musical Instruments, Institutes of Arts, Rivne State University of Humanities, Rivne, Ukraine

${ }^{2}$ Department of Musical-Instrumental Training of Teachers, Faculty of Arts, H. S. Skovoroda Kharkiv National Pedagogical University, Kharkiv, Ukraine

${ }^{3}$ Department of Preschool and Primary Education Methods, Volodymyr Vynnychenko Central Ukrainian State Pedagogical University, Kropyvnytskyi, Ukraine (portjulia@ukr.net)

${ }^{4}$ Department of General Law and Humanities, Ivano-Frankivsk Law Institute of the National University "Odessa Law Academy", Ivano-Frankivsk, Ukraine

${ }^{5}$ International relationship Department Kiev National University of Culture and Arts, Kyiv, Ukraine 


\title{
Journal for Educators, Teachers and Trainers, Vol. 11 (1) \\ ISSN 1989 - 9572 \\ https://jett.labosfor.com/
}

\section{Increasing Motivation of Primary School Pupils' Studying}

Viktoriia I. Prokopchuk ${ }^{1}$, Iryna Revenko ${ }^{2}$, Yuliya M. Demchenko ${ }^{3}$, Olga B. Blaga ${ }^{4}$, Vitaliia V. Tarasova ${ }^{5}$

${ }^{1}$ Department of Playing Musical Instruments, Institutes of Arts, Rivne State University of Humanities, Rivne, Ukraine

${ }^{2}$ Department of Musical-Instrumental Training of Teachers, Faculty of Arts, H. S. Skovoroda Kharkiv National Pedagogical University, Kharkiv, Ukraine

${ }^{3}$ Department of Preschool and Primary Education Methods, Volodymyr Vynnychenko Central Ukrainian State Pedagogical University, Kropyvnytskyi, Ukraine (portjulia@ukr.net)

${ }^{4}$ Department of General Law and Humanities, Ivano-Frankivsk Law Institute of the National University "Odessa Law Academy", Ivano-Frankivsk, Ukraine

${ }^{5}$ International relationship Department Kiev National University of Culture and Arts, Kyiv, Ukraine

\begin{abstract}
The scientific investigation reveals the topic of increasing the motivation of primary school pupils' studying, which is relevant today and requires careful study. Data from the Institute of Educational Analytics, the German Internet Portal of statistics Statista, the World Bank and the international organization World Population Review have been used in the context of solving the problem of increasing motivation of primary school pupils' studying in in Ukraine and Germany. The processing of statistics requires the use of methods of theoretical substantiation, analysis and comparison in the study. According to the World Bank's education quality rating, Germany was ranked as one of the best countries with a high level of education quality in 2015-2017, and Ukraine ranked the 54th and the 56th places respectively. It has been found that today both in Germany and Ukraine an improvement of pupils' studying at school is observed, it has been found that in the period of 2016-2018 the number of elementary schools in Ukraine decreased sharply, in Germany during 2008-2018 it has been a similar situation. The results of the series of studies have shown the presence in the practice of the activities of educators, psychologists and scientists, specializing in the study of this issue, a significant number of available and potential ways for increasing motivation. It has been studied the reasons for the learning motivation decrease and the factors influencing it, as well as five levels of learning motivation in primary school. In author's opinion, the ARCS model is relevant nowadays, because it focuses on the motivational aspects of the educational environment and includes four components of motivation. It has been proved, that it is necessary to provide the innovative teaching methods in Ukrainian school during evaluation process. IT programs, that can improve the learning process and increase motivation in primary education has been presented.
\end{abstract}

Keywords: Motivation, Studying (Learning), Primary School, Secondary School of I Degree.

\section{INTRODUCTION}

The basic tasks of the modern education system of each country, as of today, include: increasing the effectiveness of studying, developing the imagination and improving thinking, forming intelligence, self-realization, improving communication and self-expression of pupils. Undoubtedly, the achievement of such tasks is influenced by many factors. However, special attention should be paid to such elements as the quality of education, the level of 


\section{Journal for Educators, Teachers and Trainers, Vol. 11 (1) \\ ISSN 1989 - 9572 \\ https://jett.labosfor.com/}

teaching, the organization of the educational process and so on. Despite this, the problem of motivating pupils to study, and especially of younger pupils, is especially important and extremely relevant today. This, in turn, will increase the success of pupils' studying activities and promote the formation of abilities, knowledge and practical skills. Thus, the topic of increasing the motivation of primary school pupils' studying is quite relevant today and needs a thorough study.

The purpose is to analyze the current situation in the primary education in Germany and Ukraine, compare the quantity of schools in these countries, identify the factors influencing the process of motivation and ways to increase it in order to improve the educational process in our country.

\section{LITERATURE REVIEW}

It has been established that this problem is presented by researches of many domestic and foreign scientists and pedagogues-practitioners in the context of substantiation of the relevance of the topic of this scientific paper, which is based on increasing motivation to study the pupils of primary school.

Thus, according to Khivrenko (2014), it has been found that the motivation of primary school pupils' studying is divided into two types:

1) external motivation (when a pupil studies only for the sake of praise from teachers or/and parents);

2) internal motivation (when studying is aimed at achieving the specific goals and interests of pupils and, at the same time, the student's self-realization occurs).

Voronova (2007), while sharing the position of many psychologists and educators, notes the following levels of educational motivation:

a) high level of educational motivation, which indicates a significant educational activity of pupils;

b) good level of educational motivation, which indicates that pupils cope with learning activities;

c) level at which pupils' attitudes toward school are positive but not in the direction of learning activities;

d) low level of educational motivation, which indicates that pupils are not interested in attending school;

f) level at which pupils' attitudes toward school are negative because they have significant learning difficulties.

Guzenko (2002) proves in the dissertation research "Formation of motivation of younger pupils' studying under the conditions of personally oriented education" that the formation of motivation of younger pupils' studying is influenced by such factors as:

1) social and pedagogical (family, staff, media, preschools, extracurricular institutions);

2) psychological factors (preschool motivational readiness, volitional act, individual and age characteristics of the pupil);

3) didactic factors (planning and combining key components of the lesson, organizing the lesson learning process, controlling and analyzing the results of the lesson learning process).

In addition, the stimulation of younger pupils' motivation to study is influenced by the following factors, namely: a) how much the pupil is passionate about the result; b) how much free choice of tasks and ways of their fulfillment the pupil has; c) whether in the past there were motivations to study; d) what relationship and information exchange exists between the teacher and the pupil (Guzenko, 2002).

The study's results of the psychological foundations of the motivation's development for younger pupils' studying, obtained by Chorney (2014), indicate that younger pupils have quite large reserves for the formation of motivation. They should definitely be used by teachers, due to the fact that the level of these reserves begins to decline when pupils become older. Nevertheless, the very process of creating motivation of younger pupils' studying is influenced by the environment, where the pupil is located and the pupil's attitude to the educational process (Chorney, 2014). 
However, Savchenko (2015), in the context of studying the peculiarities of the motivation's formation for younger pupils' studying, believes that the construction of a qualitative and effective educational process depends on the fulfillment of a number of the following conditions:

1) formation of the pupils' proper attitude towards their own success in studying, as to the particular values of their lives;

2) achieving humanization of the relationship between the teacher and the pupils;

3) formation of a favorable educational and development environment;

4) formation of pupils' desire for curiosity, cognitive interest;

5) enhancement of cognitive processes by pupils;

6) formation of pupils' responsibility towards attitude to the educational process, etc.

Babayan (2004) in his dissertation research states that increase of younger pupils' motivation to study can be achieved due to development of pupils' skills to reflexively evaluate themselves, thus interpreting this ability to focus positive participation in the educational process.

In order to increase the motivation of primary school pupils' studying, Judina (2007) proposes to introduce the appropriate integrated courses into the practice that will promote the self-improvement of pupils, vision of the future profession, the formation of positive experiences, intellectual development, improving classroom relationships. Gordyeyeva and Kulyk (2010) propose to use grammar games in the framework of increasing younger pupils' motivation for English-speaking communicative activity. Such games will increase the level of communicating activity of younger pupils and, thus, increase their interest in learning English (Gordyeyeva \& Kulyk, (2010). Learning language with motivation - is a variety of facts about student behavior (Ortega, 2009; VanPatten \& Benati, 2010). As an alternative, Polevicova (2004) believes that it is possible to increase the younger pupils' motivation to study the mother tongue at the expense of an appropriate system of creative exercises: in the first class it is necessary to develop pupils' speaking and writing, their ability to use the language as an important means of communication; in the second grade you need to study the language and speech phenomena; third grade pupils need to develop the ability to model sentences in accordance with the tasks of speech; in fourth grade, pupils have to acquire knowledge of grammar, spelling, phonetics and acquire skills in working with the text. Despite this, Shyshenko (2016) notes that the following scope of activities should be included for proper formation of the motivation of primary school pupils' studying, namely:

1) use of various game techniques by the teacher at the lesson;

2) involvement in active cognitive activity;

3) carrying out unconventional forms of the educational process, including conducting competitions, visiting excursions, making trips.

Bilous (2017) proposes to use mobile applications in the context of increasing the motivation to study mathematics by elementary school pupils. According to the scientist, the use of electronic devices at Math lessons as well as at other lessons at primary school will provide the development of abilities and skills of pupils for using information technologies; they will allow pupils to receive appropriate information about the environment, exchange information and use it for the purpose of gaining and expanding practical experience (Bilous, 2017).

In the context of the disclosure of the subject matter of this scientific paper, it should be noted that Tiedemann and Billmann-Mahecha (2007), having analyzed the influence of motivational factors of primary pupils' studying, came to the conclusion that the primary teachers (or otherwise non-specialized teachers) have better influence over stimulation of the motivation of primary school pupils' studying. This is due to the fact that these teachers assess the younger pupils' knowledge of the subject less firmly, as contrasted with the subject teachers. Such actions, in turn, influence the formation of a positive self-concept of younger pupils; as a result, they receive the increased pleasure from studying (Tiedemann \& Billmann-Mahecha, 2007).

At the same time, German scholars (Helmke et al., 2007) emphasize that the key elements of the success of a younger pupil's education are the individual's level of pupil's development, as well as the level of teaching of scientific information. A younger student's learning potential simultaneously is shaped by his / her previous knowledge, language, intellectual ability, memory and learning strategy (Helmke et al., 2007).

Hellmich, Görel and Schwab (2016), as an alternative, point out that the introduction and application of inclusive lessons in educational activities will affect the increase of motivation of primary school pupils' studying.

\section{MATERIALS AND METHODS OF RESEARCH}


The data from the Institute of Educational Analytics, the German statistics portal Statista, the World Bank and the international organization World Population Review were used in the context of solving the problem of increasing motivation of primary school pupils' studying.

The processing of statistics requires the use of a comparison method in the study, as well as methods of theoretical generalization. We compared motivation in language learning with other types of motivation, where learning with motivation - is a variety of facts about student behavior (Ortega, 2009; VanPatten \& Benati, 2010). We determined the differences in the seven motivation measures between students, who study in traditional classes and by elearning (Rovai et al., 2007).

It is used a multivariate analysis of variance Socio-psychological theory of L2 motivation (Gardner, 1985) to analyze the structure of motivation and the existing relationships between student' motivation and their achievement in L2. The study of motivation is the basis for different disciplines, because it allows to analyze what people would do (Deci \& Ryan, 2000), the category of "motivation" can increase efficiency in learning and professional work (Frey, Homberger \& Osterloh, 2011; Gagné \& Deci, 2005). It is also important for staff productivity and efficiency (Ryan \& Deci, 2000).

\section{RESEARCH RESULTS}

According to the quality rating of the World Bank's (2017) education system during 2007-2017, Germany is one of the best countries with a high level of quality in the education system. In 2017, the position of Germany in the ranking improved significantly compared to recent years, because this country entered the top ten countries in terms of the quality of the education system. With regard to the quality of the education system in Ukraine, the places of our country in this rating were in extremely unstable dynamics. Therefore, Ukraine ranked the 79th place among 151 countries and was below the world average in 2013. Instead, in 2015-2017 Ukraine's position improved slightly and normalized, as Ukraine ranked the 54th and the 56th places respectively in the ranking (Figure 1). According to the results of surveys and researches conducted by the World Population Review (2020), it is worth noting that Germany is among the ten most educated countries in the world. Thus, according to the rating of education, Germany took the 4th place in 2018 .

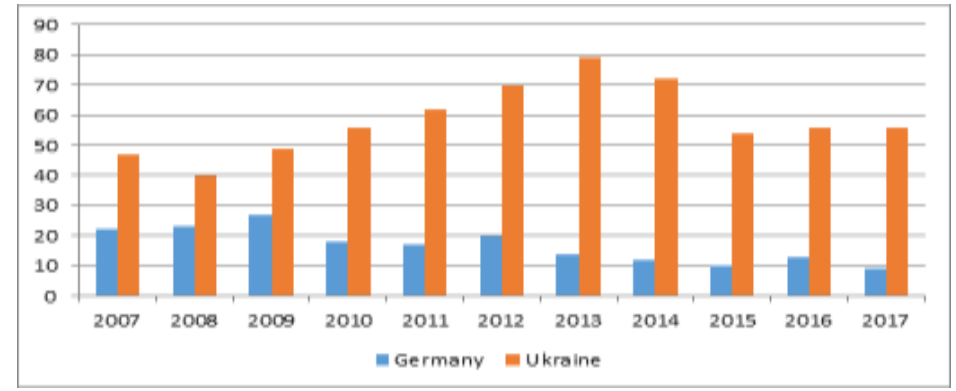

Figure 1: Quality rating of the education system in Germany and Ukraine, rank

Source: The World Bank (2017)

Based on the results of a study, conducted by the Institute for Educational Analytics, it was found that in the period of 2016-2018, the number of primary schools in Ukraine decreased sharply (attention is focused only on secondary schools of the first degree).

Thus, in 2019, the number of secondary schools of the first degree decreased by $32,0 \%$, compared to the beginning of the analyzed period (Table 1). In particular, a significant reduction in the number of secondary schools of the first degree occurred in rural areas (by 39,2\% in 2019 compared to 2016). As for the urban area, the decrease in the number of schools in the same period was only $19,5 \%$.

Table 1: Dynamics of development of primary school (secondary school of I degree) in Ukraine

\begin{tabular}{|l|l|l|l|l|}
\hline Indicators & 2016 & 2017 & 2018 & 2019 \\
\hline Number of primary schools, units & 1047 & 856 & 756 & 712 \\
\hline Total & 128 & 126 & 133 & 153 \\
\hline Urban area & 128 & 730 & 623 & 559 \\
\hline Countryside & 919 & 46058 & 46949 & 47670 \\
\hline Number of pupils, persons
\end{tabular}




\begin{tabular}{|l|l|l|l|l|}
\hline Urban area & 32540 & 32724 & 34832 & 36918 \\
\hline Countryside & 16140 & 13334 & 12117 & 10752 \\
\hline Number of teachers, persons \\
\hline Total & 5859 & 5127 & 5015 & 5016 \\
\hline Urban area & 2403 & 2374 & 2537 & 2744 \\
\hline Countryside & 3456 & 2753 & 2478 & 2272 \\
\hline
\end{tabular}

Source: Institute of Educational Analytics (n./d.)

As for the number of pupils enrolled in secondary schools of the first degree, the situation is somewhat different here. During 2018 - 2019, the number of pupils increased (by 1,9\% and 1,5\%, respectively, compared to the previous year) after the decrease in 2017 (by 5,4\%). Due to the gradual increase in the proportion of pupils in urban areas, there has been a sharp decrease in the proportion of pupils in rural areas. Regarding the situation with teachers, the total number of teachers in 2016-2019 gradually decreased every year (except for 2019) and decreased by $14,4 \%$ in 2019 , compared to 2016 . In contrast to the overall indicators, the number of urban area's teachers in the period of 2018-2019 has shown a significant increase, compared to previous years. There was a decrease in the share of rural teachers against the background of an increase in the share of urban teachers, which decreased by $34,3 \%$ in 2019 , compared to the beginning of the analyzed period.

In the context of the study of the situation in the field of primary education in Germany, the following data have been revealed. Thus, in the period of 2008-2018, the dynamics of the number of primary schools in Germany tended to decrease. In 2018, the number of primary schools decreased by $6,7 \%$, compared to the beginning of the analyzed period, that is 1101 primary schools were closed or reorganized (Figure 2).

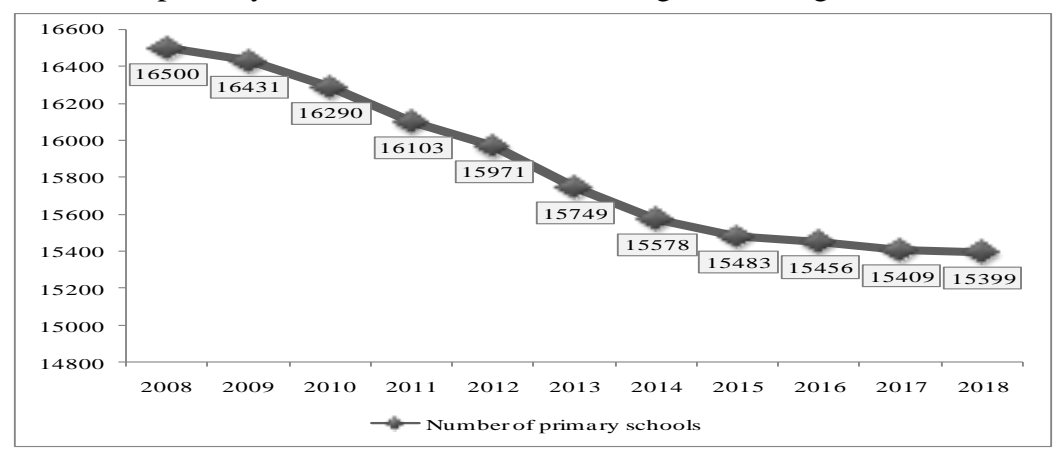

Figure 2: Number of primary schools in Germany

Source: Statista (n./d.)

Despite the decline in the number of primary schools in Germany, the number of pupils in these schools is increased every year. Therefore, in 2017, 2800,4 thousand pupils were enrolled into 15409 primary schools, which is by 92000 more than in 2013, when pupils had been studying at 15749 primary schools (Table 2).

Table 2: The dynamics of the development of the primary school in Germany

\begin{tabular}{|l|l|l|l|l|l|}
\hline Indicators & 2013 & 2014 & 2015 & 2016 & 2017 \\
\hline Number of pupils at primary school, thousand & 2708,4 & 2708,8 & 2716,7 & 2773,4 & 2800,4 \\
\hline Average number of pupils in one class & 20,7 & 20,7 & 20,7 & 20,8 & 20,9 \\
\hline Ratio of pupils and teachers & 16,4 & 16,3 & 16,2 & 16,3 & 16,2 \\
\hline Lessons taught per student & 1,5 & 1,5 & 1,5 & 1,5 & 1,5 \\
\hline Lessons taught in class & 30,1 & 30,3 & 30,5 & 30,5 & 31 \\
\hline
\end{tabular}

Source: Kultusminister Konferenz (n./d.)

Studies show that in recent years positive changes have seen in the primary education system of Germany. These tendencies are evidenced by the increase in the number of lessons taught per pupil and the number of lessons taught per class. At the same time, there is a decrease in the number of teachers in relation to their ratio to pupils in the period of 2013-2017.

\section{DISCUSSION}

The results of the series of studies on enhancing motivation of primary school pupils' studying have shown that educators, teachers, psychologists and scientists, specialize in the study of this issue, obtain a number of available 
and potential ways to increase motivation in their practice. At the same time, it has been established that teachers have a special influence on the primary school pupils' educational process.

In our opinion, motivation should be considered as a constant process of forming learning motives in order to acquire knowledge, perform tasks and control their work. That is why in the formation of positive motivation to learn, especially in primary school, a great role is played by the support of the teacher, good marks, that characterize the educational activities of the pupil. Scientists believe that positive assessment, encouragement or condemnation are the influences that motivate learning, and should take into account the individual characteristics and self-esteem of pupils. The negative attitude to learning is influenced by subjective reasons: lack of interest, personal factor, unwillingness to go to school, and objective: lack of opportunity to go to school, family problems, health problems.

All over the world, the level of motivation is influenced by the following factors: the country's educational system; level of educational in school or university; organization of the educational process (use of innovative teaching methods); subjective features of the child (age, intellectual opportunities, abilities, self-esteem, interaction with other pupils); subjective features of the teacher and his attitude to the child; features of the subject.

The main reasons for the decline in pupils' motivation to study are:

- misunderstanding of the purpose of training;

- low productivity of educational activities;

- health of the child;

- the relationship between pupil and teacher;

- personal significance of the subject;

- fear of school.

According to Lepper and Malone (1987), seven factors have strongly influence on motivation: challenges, curiosity, control, fiction, competition, collaboration, recognition. We consider that, it is necessary to improve their interpretation and meaning:

1. challenges of our time;

2. the fear of new knowledge;

3. control over the process of obtaining knowledge;

4. the abundance of information and the speed of its updating;

5. huge competition;

6. team relationships;

7. recognition of pupils' success.

Table 3 shows the five levels of learning motivation in primary school:

Table 3: Levels of motivation

\begin{tabular}{|l|l|}
\hline evel & Definition \\
\hline The first level & $\begin{array}{l}\text { high level of school motivation and learning activity (the child has a cognitive motive, the } \\
\text { desire to most successfully fulfill all the proposed school requirements, pupil follows the } \\
\text { instructions of the teacher, is responsible and strives for the highest grades; }\end{array}$ \\
\hline $\begin{array}{l}\text { The second } \\
\text { level }\end{array}$ & $\begin{array}{l}\text { good school motivation (the pupil successfully copes with educational activities and receives } \\
\text { good grades); }\end{array}$ \\
\hline The third level & $\begin{array}{l}\text { positive attitude to school, but the greatest interest is shown in extracurricular activities } \\
\text { (children feel good at school, have many friends, but the educational process attracts them } \\
\text { little); }\end{array}$ \\
\hline $\begin{array}{l}\text { The fourth } \\
\text { level }\end{array}$ & $\begin{array}{l}\text { low school motivation (children attend school reluctantly and miss classes, are distracted by } \\
\text { extraneous affairs and games, are in the process of adapting to school); }\end{array}$ \\
\hline The fifth level & $\begin{array}{l}\text { a negative attitude to school (children have difficulties, do not cope with learning activities, } \\
\text { have problems in communication with classmates and in relationships with the teacher, may } \\
\text { have neuropsychiatric disorders). }\end{array}$ \\
\hline
\end{tabular}

Source: Author's work

Based on data from the Institute of Educational Analytics, the German statistics portal Statista, the World Bank and the international organization World Population Review, it has been revealed that as of today there is an improvement in student educational success school in Germany and Ukraine, due to the fact the positions of these countries in the quality rating of the education system are good enough. 
The environment greatly influences on students' internal motivation and involvement, and is capable to support the creativity. In a study (Samson, 2015, p. 161) it is mentioned, that creative solving of problems stimulates student's engagement and helps to find "strategies that attract and motivate students, promote deeper learning, and foster effective problem solving and critical thinking skills." Davies et al. $(2013$, p. 88) identified the key learning factors, necessary to support the development of creative children: physical environment, availability of resources / materials, factors of external and pedagogical environment, spending time outside school, learning process games, rational use of time and interaction with other participants of the educational process.

In the research of Kolba $(2014$, p. 38), "learning is the process by which knowledge is created through the transformation of experience." In Germany, experiential learning occupies a special place and is based on the acquisition of knowledge, based on experience that is transformed through self-reflection, feedback and selfcontrol in the learning process.

Lack of motivation negatively affects the quality of knowledge, contributes to the frustration and irritation of students, hinders productivity and their future professional development. We believe that the ARCS model, studied in the work (Keller, 1983), is relevant nowadays, it focuses on the motivational aspects of the educational environment and includes four components of motivation: interest, relevance of educational material, long-term success and internal and external remuneration satisfaction (Figure 3).

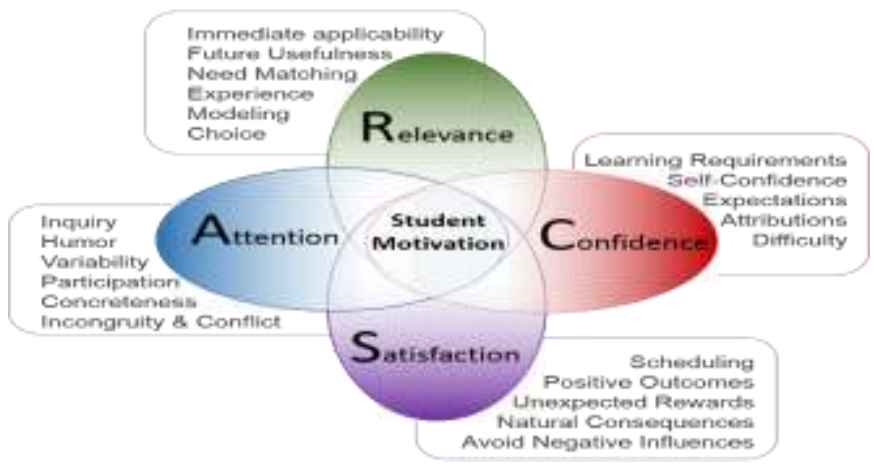

Figure 3: ARCS model in education

Source: Souders (2020)

Modern students are more actively involved in the learning process, when they are interested in solving tests, doing independent work. Shernoff, Mehta and Atkins (2011) argue that teachers are able to motivate children, increase the number of students in the classroom, when the learning process meets the expectations of children and makes contribution to their success. When teachers pay enough attention and control the process of learning, students feel more satisfied, that's why the process of evaluating their activities also plays an important role.

Today the German school system is in a process of changes in response to the implementation of digital technologies at school, which is also emplemented in other spheres around the world. In Germany, the disciplines are grouped into subject cycles, which helps to better establish interdisciplinary links and acquire the necessary skills for further application of the acquired knowledge in professional activities and to obtain an effective result The German primary school curriculum does not include the subjects "Health", "Informatics", "Science", "Labor", instead, students study "Sports", "Maths", "Homeland and the world around it". Throughout all disciplines, pupils learn computer literacy using multimedia boards and IT technologies. The same disciplines for our countries are: native language, foreign language, maths, music, sports.

The reform of the education system and the variety of educational processes have extended the need to improve traditional teaching methods and the use of interactive technologies. Also, it is necessary to change the nature of teacher-student relations in primary school, which should depend on children's individuality and interests. Today all over the world today, the pupil is becoming an active participant in the learning process, and education contributes to the intensification of educational and cognitive activities. So European countries and especially Germany is an innovator in implementing active teaching methods, that involve not only receiving and learning material in practice. According to Gruschka (2007), the methods and technologies of programmed, multimedia, problem-solving, project-based learning have become widely used in the educational practice of primary schools in the eastern lands of Germany. 
We believe that the evaluation process is as important as the process of providing the material by teacher, so we believe that the following innovative methods are currently relevant in Ukraine:

1. The "My Achievements" notebook - is formed by the teacher during the learning process gradually in the computer, and at the end of the year he and the parents can easily review the pupil's achievements. It can look like a paper book, with creative pockets for storing the child's achievements on each page or a virtual book with the child's progress in electronic form (photos of works, scanned drawings, videos).

2. The Knowledge Board - is an innovative resource for primary school, with a wide range of various entertaining and interesting cognitive tasks for pupils, which allows the teacher to save his time. Knowledge Board helps teachers and students collaborate by using more opportunities for individual or general learning, taking into account students' interests and new learning opportunities.

3. Student portfolio - a popular method of assessment in the second grade, which involves collecting success and achievements of the pupil. This is a personal document in the form of a folder with tables on each page. The data is filled in by students first times under the guidance of the teacher each week and then at the child's own request. The portfolio includes drawings, samples of written works, creative and project activities (posters, books, own products, audio recordings with the performance of a poem, songs, videos with a presentation of the project, etc.). 4. Working with cards - is a set of a blackboard and a set of thematic cards (for each topic of the discipline). The board for 1st and 2nd grade students consists of 6 buttons of different colors, and for 3rd and 4th grades - of 10 . The cards contain material about culture, ecology, healthy living, environment, words from a foreign language, some cards with audio.

The Table 4 presents IT programs to improve the learning process and increase motivation in primary education.

Table 4: Innovative programs to improve the learning process and students' motivation

\begin{tabular}{|l|l|}
\hline Didactic task & Examples of programes \\
\hline Providing training information & - WordPress \\
& - Moodle \\
& - Google class \\
\hline Advice & - MOOC \\
& - Bigbluebutoon \\
& - Skype \\
& - Hangouts \\
& - Padlet \\
\hline Exchange of experience & - Blogger \\
& - Bigbluebutoon, Skype, Hangouts \\
& - Viber \\
& - Disk Google, Google Plus \\
& - One Drive \\
& - Office 365 \\
\hline Control and evaluation & - Google Apps \\
& - Padlet \\
& - Google Forms \\
& - Kahoot \\
& - Plickers \\
& - Moodle \\
\hline
\end{tabular}

Source: Author's work

In modern conditions, learning should be technologically intensive, the stimulation of organizational, psychological and methodological support for the educational process allows our country to reach a new level of management of the learning process and increase pupils' motivation.

\section{CONCLUSION}

The key task of the modern education system in Ukraine is to improve the quality of education. The solution of the problem of study motivation is closely connected with quality of education, because the lack of motivation negatively affects the quality of knowledge, stimulate the frustration and irritation of pupils, hinders productivity and their future professional development. In our opinion, it is nesecarry to put attention to the factors, influenced the motivation: challenges of our time, the fear of new knowledge, control over the process of obtaining knowledge, the abundance of information and the speed of its updating, huge competition, team relationships, 
recognition of success. Such countries as Ukraine and Germany are now actively engaged in solving problems concerning increasing motivation and the educational process. The results of studies indicate the interest of German children in modern technology in early childhood. That's why, adopting the experience of Germany, it is necessary to improve domestic primary education, using modern technology to increase the interest and motivation of pupils to obtain knowledge. The use of IT technology in order to increase the pupils' interest will increase their success, motivation and improve the level and quality of education in our country.

\section{REFERENCES}

1. Babayan, Y. O. (2004). Development of reflexive appreciation as factor of achievement motivation of junior schoolchildren. PhD abstract thesis. M.P. Dragomanova National Pedagogical University, Kyiv, Ukraine.

2. Bilous, V. V. (2017). Mobile applications for teaching mathematics as a means to enhance motivation for junior high school students. Open educational e-environment of modern University, 3, 303-309.

3. Chorney, I. (2014). Psychological aspects of the development of junior school motivation in the educational process. New Pedagogical Thought, 4(80), 163-165.

4. Davies, D., Jindal-Snape, D., Collier, C., Digby, R., Hay, P., \& Howe, A. (2013). Creative learning environments in education: A systematic literature review. Thinking Skills and Creativity, 8, 8091.

5. Deci, E. L. \& Ryan, R. M. (2000). The "What" and "Why" of Goal Pursuits: Human Needs and the Self-Determination of Behavior. Psychological Inquiry, 11(4), 227-268.

6. Frey, B. S., Homberger, F., \& Osterloh, M. (2013). Organizational control systems and pay for performance in the public service. Organization Studies, 34(7), 949-972.

7. Gagné, M., \&. Deci, E.L. (2005). Self-determination theory and work motivation. Journal of Organisation Behavior, 26(4), 331-362.

8. Gardner, R. C. (1985). Social Psychology and Second Language Learning: The Role of Atttitude and Motivation. London, UK: Edward Arnold.

9. Gordyeyeva, A., \& Kulyk, S. (2010). Motivation of English communicative activity of junior pupils with the help of a grammar game. Foreign Languages, 3, 17-21.

10. Gruschka, A. (2007). "Was ist guter Unterricht?". Über neue Allgemein-Modellierungen aus dem Geiste der empirischen Unterrichtsforschung ["What is good teaching?" About new general modeling from the spirit of empirical teaching research]. Pädagogische Korrespondenz, 36, 10-43.

11. Guzenko, O. A. (2002). The formation of motivation of studying junior pupils in conditions of individual oriental education. PhD abstract thesis. National Pedagogical University named after M. P. Dragomanov, Kyiv, Ukraine.

12. Hellmich, F., Görel, G., \& Schwab, S. (2016). Einstellungen und Motivation von Lehramtsstudentinnen und -studenten in Bezug auf den inklusiven Unterricht in der Grundschule. Ein Vergleich zwischen Deutschland und Österreich [Attitudes and motivation of student teachers in relation to inclusive teaching in primary school. A comparison between Germany and Austria]. Empirische Sonderpädagogik, 1, 67-85.

13. Helmke, A., Helmke, T., Heyne, N., Hosenfeld, A., Kleinbub, I., Schrader, F.-W., \& Wagner, W. (2007). Erfassung, Bewertung und Verbesserung des Grundschulunterrichts: Forschungsstand, Probleme und Perspektiven [Recording, evaluation and improvement of primary school teaching: state of research, problems and perspectives]. In: Möller K., Hanke P., Beinbrech C., Hein A.K., Kleickmann T., Schages R. (eds) Qualit Ät von Grundschulunterricht [Quality of primary education] (pp. 17-34). VS Verlag für Sozialwissenschaften. https://doi.org/10.1007/978-3-53190755-0_2

14. Institute of Educational Analytics. (n./d.). Retrieved from https://iea.gov.ua 
15. Judina, N. O. (2007). Features of the structure of motivation of junior schoolchildren in integrated learning. Praktychna psykhologhija ta socialjna robota, 9, 46-51.

16. Khivrenko, S. M. (2014). Formation of positive motivation in junior schoolchildren as a psychological and pedagogical condition for creating a favorable learning environment. Osvita.ua. Retrieved from https://osvita.ua/school/lessons_summary/edu_technology/45023/

17. Kultusminister Konferenz. (n./d.). Retrieved from https://www.kmk.org

18. Lepper, M. R. \& Malone, T. W. (1987). Intrinsic motivation and instructional effectiveness in computer-based education. In: Snow, R. E., \& Farr, M. J. (Eds.), Aptitude, learning, and instruction: Vol. 3. Cognative and affective process analysis (pp. 255-286). Hillsdale, NJ: Erlbaum.

19. Ortega, L. (2009). Understanding second language acquisition. London, UK: Hodder Education.

20. Polevicova, O. B. (2004). System of creative exercises as a method of motivation's development to study the native language by junior students. PhD thesis. Kherson State University, Kherson, Ukraine.

21. Rovai, A., Ponton, M., Wighting, M., \& Baker, J. (2007). A comparative analysis of student motivation in traditional classroom and e-learning courses. International Journal on E-Learning, 6(3), 413-432.

22. Ryan, R. M., \& Deci, E. L. (2000). Self-determination theory and the facilitation of intrinsic motivation, social development and well-being. American Psychologist, 55(1), 68-87.

23. Samson, P. L. (2015). Fostering student engagement: Creative problem-solving in small group facilitations. Collected Essays on Learning and Teaching, 8, 153-164.

24. Savchenko, O. (2015). Diagnostics and didactic conditions for the formation of the junior schoolchildren's motivation of the ability to learn. Ukrainian Educational Journal, 1, 85-98.

25. Shernoff, E., Mehta, T., \& Atkins, M. (2011). Qualitative study of the sources and impact of stress among urban teachers. School Mental Health, 3(2), 59-69.

26. Shyshenko, V. O. (2016). Formation of young schoolchildren's positive motivation to educationalcognitive activity. Ridna shkola, 4, 76-80.

27. Souders, B. (2020). Motivation in Education: What it Takes to Motivate Our Kids. PositivePsychology. Retrieved from https:// positivepsychology.com/motivation-education

28. Statista. (n./d.). Retrieved from https://de.statista.com

29. The World Bank. (2017). Quality of the Education System, Value. Retrieved from https://tcdata360.worldbank.org/indicators/h00c21acb/

30. Tiedemann, J., \& Billmann-Mahecha, E. (2007). Macht das Fachstudium einen Unterschied? Zur Rolle der Lehrerexpertise für Lernerfolg und Motivation in der Grundschule [Does the subject make a difference? On the role of teacher expertise in learning success and motivation in primary school]. Zeitschrift für Pädagogik, 53, 58-73.

31. VanPatten, B., \& Benati, A. G. (2010). Key terms in second language acquisition. London, UK: Continuum International Publishing Group.

32. Voronova, N. A. (2007). Motivation of educational activity of junior schoolchildren. Pedagogical sciences, 24, 84-89.

33. World Population Review. (2020). Education Rankings by Country 2020. Retrieved from http://worldpopulationreview.com/countries/education-rankings-by-country/ 